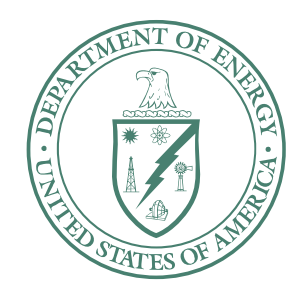

U.S. Department of Energy

Idaho Operations Office

\title{
Public Participation Plan for Waste Area Group 7 Operable Unit 7-13/14 at the Idaho National Laboratory Site
}

July 2007 


\section{Public Participation Plan for Waste Area Group 7 Operable Unit 7-13/14 at the Idaho National Laboratory Site}

July 2007 



\section{CONTENTS}

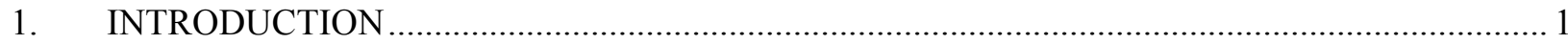

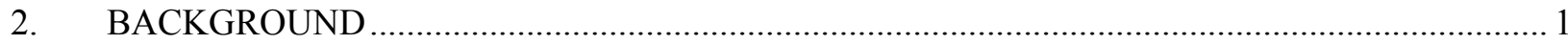

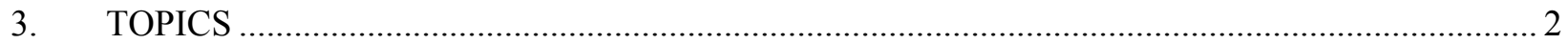

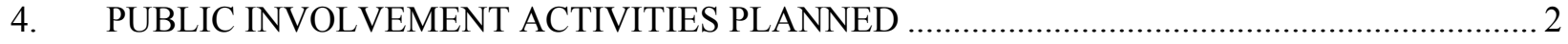

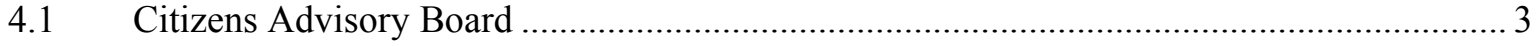

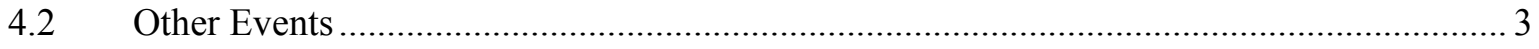

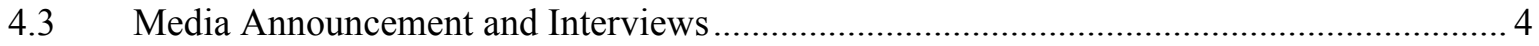

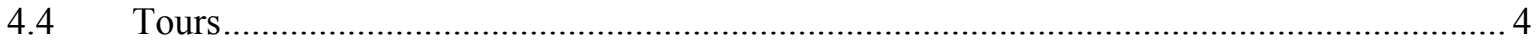

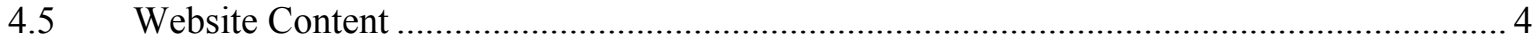

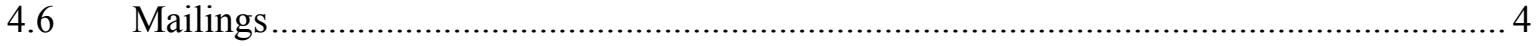

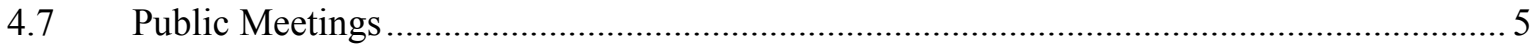

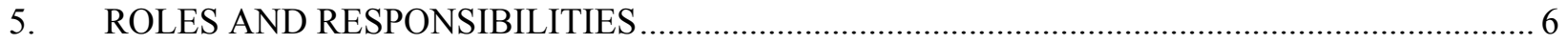

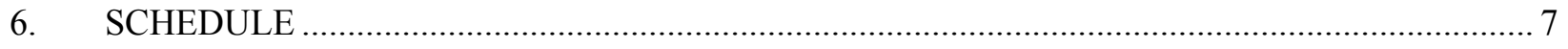

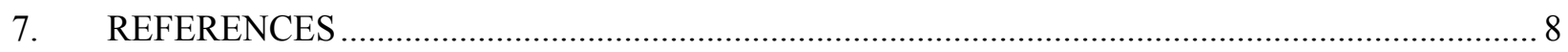

\section{FIGURE}

1. Potential open house poster session and public meeting room format ........................................ 5

\section{TABLES}

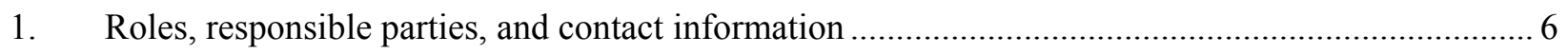

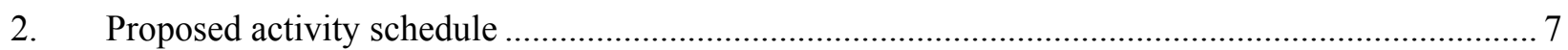




\section{Public Participation Plan for Waste Area Group 7 Operable Unit 7-13/14 at the Idaho National Laboratory Site}

\section{INTRODUCTION}

This Public Participation Plan outlines activities being planned to: (1) brief the public on results of the remedial investigation and feasibility study, (2) discuss the proposed plan for remediation of Operable Unit 7-13/14 with the public, and (3) encourage public participation in the decision-making process. Operable Unit 7-13/14 is the Comprehensive Remedial Investigation/Feasibility Study for Waste Area Group 7. Analysis focuses on the Subsurface Disposal Area (SDA) within the Radioactive Waste Management Complex at the Idaho National Laboratory (Site). This plan, a supplement to the Idaho National Laboratory Community Relations Plan (DOE-ID 2004), will be updated as necessary.

The U.S. Department of Energy (DOE), Idaho Department of Environmental Quality (DEQ), and U.S. Environmental Protection Agency (EPA) will participate in the public involvement activities outlined in this plan. Collectively, DOE, DEQ, and EPA are referred to as the Agencies.

Because history has shown that implementing the minimum required public involvement activities is not sufficient for high-visibility cleanup projects, this plan outlines additional opportunities the Agencies are providing to ensure that the public's information needs are met and that the Agencies can use the public's input for decisions regarding remediation activities.

\section{BACKGROUND}

The Operable Unit 7-13/14 remedial investigation and feasibility study officially began in 1995 . At that time, a fact sheet was mailed to citizens to inform the public of the scope of the investigation and to offer briefings.

Since 1995, regular INL and ICP presentations have provided information to the Citizens Advisory Board on progress of the Operable Unit 7-13/14 Project. The general public has been informed through update fact sheets, tours, briefings, open houses, and media accounts.

In May 2006, the Agencies finalized the remedial investigation and baseline risk assessment, and DOE released the Remedial Investigation and Baseline Risk Assessment for Operable Unit 7-13/14 (Holdren et al. 2006) to the public through the INL Administrative Record. That document concluded that risk to human health and the environment exceeds threshold values if no remediation activities were implemented. A fact sheet, which served as a summary of the remedial investigation and feasibility study, was released to the 900 stakeholders on the ICP mailing list. In addition, a Spanish version of the fact sheet was developed and released.

The feasibility study report (Holdren, Bechtold, and Preussner 2007) lists remedial action objectives and evaluates a range of remedial alternatives for Operable Unit 7-13/14. A fact sheet, written in both English and Spanish, is being released concurrent with the feasibility study report posting to the INL Administrative Record. When the report is posted in the Administrative Record, the Operable Unit 7-13/14 Project will release a media advisory to stakeholders on the ICP mailing list announcing its availability and offering briefings to those interested in the content of the feasibility study. 
Based on the current schedule, the public comment period on the proposed plan is scheduled to begin by the fall of 2007 .

\section{TOPICS}

The communications and project team identified several specific topics of interest to stakeholders based on recent inquiries and past public comments surrounding cleanup of waste disposed of at Operable Unit 7-13/14; however, additional topics likely will surface once the feasibility study is published and the Agencies have selected and presented a preferred remedial alternative in the proposed plan. Topics include the following:

- $\quad$ Protection of the Snake River Plain Aquifer

- $\quad$ Uncertainty and validity of buried waste shipping and receipt records

- $\quad$ Transport of plutonium

- $\quad$ Physical setting concerns (e.g., flooding, seismology, and volcanology)

- $\quad$ Risk and uncertainty.

The Agencies will develop information to address each of these topics.

\section{PUBLIC INVOLVEMENT ACTIVITIES PLANNED} follow:

The following planned public involvement activities are discussed further in paragraphs that

- $\quad$ Briefings (to center on the feasibility study or general Idaho Cleanup Project [ICP])

- $\quad$ Briefings to the Shoshone-Bannock Tribes ${ }^{\mathrm{a}}$

- $\quad$ Media announcements and interviews

- $\quad$ Tours

- Web site content

- $\quad$ Mailings (e.g., fact sheets and proposed plan)

- $\quad$ Public meetings

- $\quad$ Citizens Advisory Board meetings

- $\quad$ Other events (e.g., INL Day at the Idaho Legislature event).

Briefings are anticipated and may be held with the following groups and individuals:

- Commissioners of the seven counties surrounding INL Site

a. A government-to-government relationship exists with the Tribes. 
- $\quad$ Elected officials and political interest groups

- Idaho Falls congressional staffs

- Idaho congressional delegation

- $\quad$ Boise congressional staff

- $\quad$ Magic Valley residents

- Idaho State Legislature

- $\quad$ Citizens Advisory Board

- $\quad$ Snake River Alliance

- $\quad$ Keep Yellowstone Nuclear Free

- $\quad$ Partnership for Science and Technology

- $\quad$ Farm Bureau

- $\quad$ Potato Growers of Idaho

- $\quad$ Regional Development Alliance

- Idaho Council on Industry and the Environment

- Economic development organizations

- $\quad$ Civic organizations

- Chambers of commerce

- Environmental and economic interest groups.

The Agencies will participate in the briefings.

\subsection{Citizens Advisory Board}

The Agencies will update the Citizens Advisory Board on the Operable Unit 7-13/14 activities during their bimonthly meetings.

\subsection{Other Events}

The ICP participated in the INL Day at the Legislature event at the Boise Capitol on February 27, 2007. The Operable Unit 7-13/14 Project was highlighted at this event. The ICP will explore participating in similar venues to discuss the project with the public. 


\subsection{Media Announcement and Interviews}

The ICP will issue media advisories about availability of the feasibility study report and the public comment period for the proposed plan. Media interviews will center on release of the feasibility study report and then at release of the proposed plan.

\subsection{Tours}

Public tours of the SDA are common as well as tours by members of the Citizens Advisory Board, media, and DOE-Headquarters senior management. Tour requests likely will increase once the OU 7-13/14 feasibility study is released.

\subsection{Website Content}

All written information related to the remedial investigation and feasibility study is available for public review on the INL Administrative Record at http://ar.inel.gov. Additional information (e.g., press releases and fact sheets) will be posted to the ICP Web page at http://Idahocleanupproject.com.

The communications group will create a video to post on its Web page and on a public domain like http://youtube.com. The video will contain aerial footage of the SDA, historical photographs showing past dumping practices, and current waste exhumation video from the Accelerated Retrieval Project at the SDA. Also, the video will be used to preface the upcoming public comment period and meetings.

Once the proposed plan is released for public comment, that document will be posted to the ICP Web page, enabling the public to send comments to the Agencies electronically.

\subsection{Mailings}

The Agencies will develop and release a fact sheet to outline results of the feasibility study.

The proposed plan will be mailed to about 900 citizens on the ICP mailing list. Additional copies will be printed to fulfill further requests for copies. The proposed plan will list public meeting locations and also will offer briefings to interested groups and individuals. In addition, the Communications group will work with other organizations to provide information to members on their mailing lists (e.g., chambers of commerce).

The process for releasing the proposed plan includes:

- $\quad$ Posting the proposed plan to the INL Administrative Record and beginning 30-day public comment period simultaneously

- $\quad$ Publishing advertisements in local newspapers: Post Register, Idaho State Journal, Arco Advertiser, Idaho Unido, Moscow Daily News, Lewiston Tribune, Idaho Statesman, Twin Falls Times-News, Sho-Ban News, Jackson Hole News and Guide, and Planet Jackson Hole

- $\quad$ Issuing news release (including details of the meetings)

- $\quad$ Mailing about 900 postcards to stakeholders on the ICP mailing list, informing people how to access the proposed plan and the specifics of the comment period 
- $\quad$ Briefings to the Shoshone-Bannock Tribes

- $\quad$ Briefing stakeholder groups and news media proactively.

\subsection{Public Meetings}

Public meetings will comprise

a. Overview of the public participation format

b. Brief presentation that generally outlines the RI/FS process and summarizes the proposed plan (see Figure 1)

c. A general question and answer session to clarify information

d. An opportunity to provide comments to a court reporter for Agency consideration in the record of decision.

Open house room
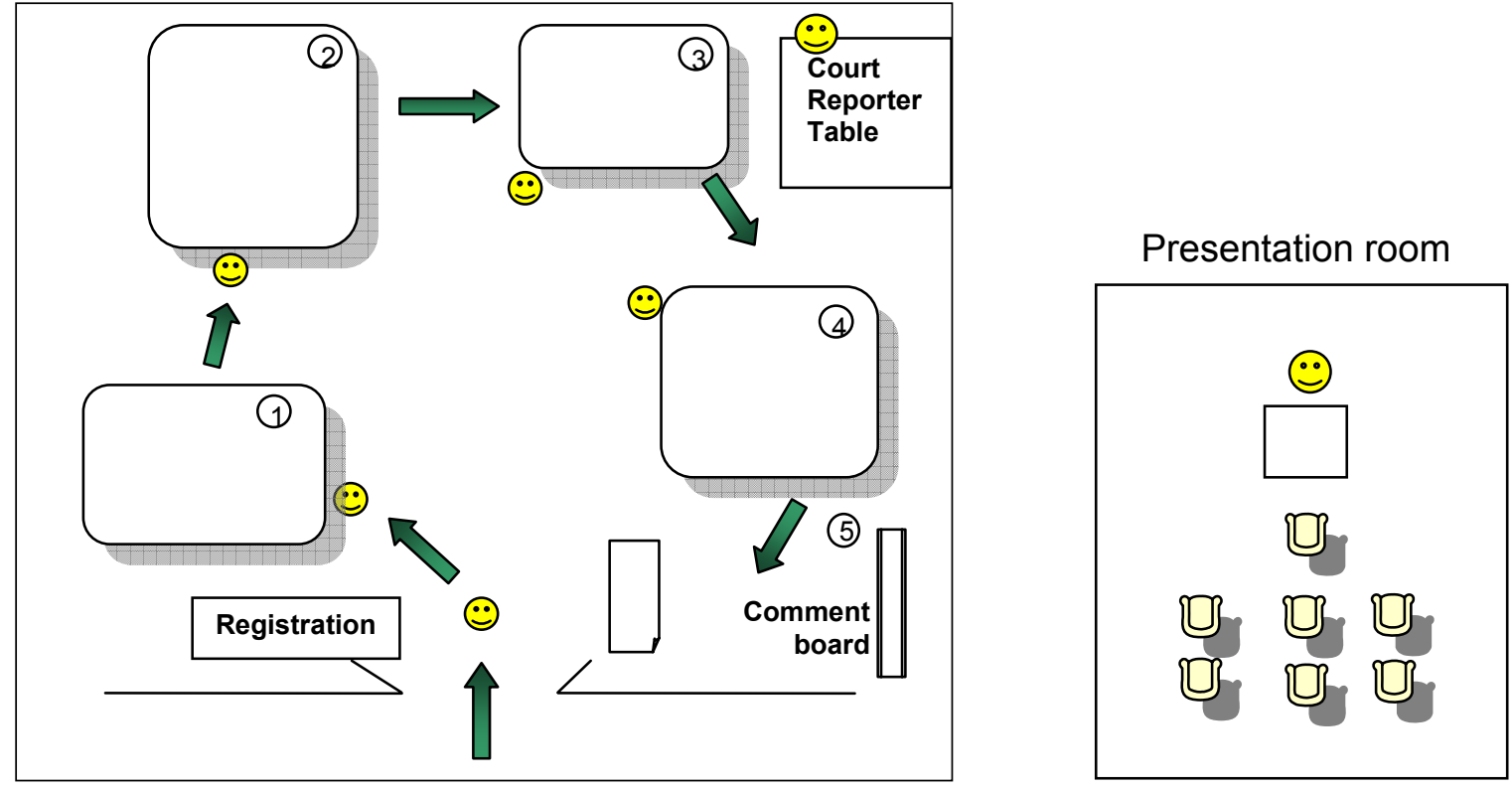

Figure 1. Potential open house poster session and public meeting room format.

The "open house" format has been implemented to address concerns by the public that traditional public meetings are not conducive to meaningful, two-way communication. Many citizens who attended previous INL public meetings, indicated they had questions and comments, but were too intimidated to participate verbally. As a result of these concerns, the Agencies piloted the open house poster session format during the Operable Unit 3-14 public meetings in August 2006. Feedback from the public was positive ( $75 \%$ of survey respondents favored this format); therefore, the Operable Unit $7-13 / 14$ public meetings will be conducted in a similar fashion.

Meetings will be held in Idaho Falls, Twin Falls, and Boise in the fall of 2007. All meetings will begin at 6 p.m. A Spanish-speaking interpreter, provided by the ICP, will be available at all three meetings to discuss the poster board session and formal comments. 


\section{ROLES AND RESPONSIBILITIES}

Table 1 lists Agency and contractor roles and the parties responsible for implementation. Activities highlighted in this public involvement plan will be carried out in cooperation with the Agencies.

Table 1. Roles, responsible parties, and contact information.

\begin{tabular}{|c|c|c|}
\hline Roles & Responsible Parties & Phone Number \\
\hline Communications contacts & $\begin{array}{l}\text { Steven Sorrell, DOE } \\
\text { Amy Lientz, ICP }\end{array}$ & $\begin{array}{l}\text { (208) } 526-1986 \\
\text { (208) } 520-7718\end{array}$ \\
\hline $\begin{array}{l}\text { ICP Waste Area Group } 7 \text { project } \\
\text { managers }\end{array}$ & $\begin{array}{l}\text { Brandt Meagher } \\
\text { Frank Webber }\end{array}$ & $\begin{array}{l}\text { (208) 526-9767 } \\
\text { (208) } 526-8507\end{array}$ \\
\hline $\begin{array}{l}\text { DOE Waste Area Group } 7 \text { project } \\
\text { manager }\end{array}$ & Mark Arenaz, DOE & (208) 526-1510 \\
\hline Idaho DEQ project manager & Daryl Koch & (208) 373-0492 \\
\hline EPA Region 10 project manager & Dennis Faulk & (509) 376-8631 \\
\hline $\begin{array}{l}\text { Stakeholder involvement and public } \\
\text { meeting logistics }\end{array}$ & Erik Simpson, ICP & (208) 526-4700 \\
\hline
\end{tabular}




\section{SCHEDULE}

Table 2 provides a proposed estimated schedule, which is subject to change.

Table 2. Proposed activity schedule.

Activity Schedule

Before Feasibility Study Availability

Develop joint-Agency response to queries and messages

Ongoing 2007

Conduct congressional briefings

February 2007

Attend INL Day at the Idaho Legislature (Boise)

February 2007

Brief Tribes

Ongoing 2007

Brief Idaho legislative committees

Ongoing 2007

Update Website content (through the INL Administrative Record)

Ongoing 2007

Conduct tours

Ongoing 2007

\section{Feasibility Study}

Post to INL Administrative Record for public review

May 2007

Release media advisory to announce feasibility study availability and accessibility of technical staff for briefings

Release feasibility study fact sheet to public

May 2007

Conduct briefings with groups listed in Section 4

May 2007

Develop information to address topics in Section 3

Begin Spring 2007

Begin Spring 2007

\section{Proposed Plan}

Release document for public comment

Fall 2007

Host open houses

Fall 2007

Release press release (and advertisement) to news media and other

Fall 2007 organizations to announce availability and accessibility of technical staff for briefings

Conduct briefings during the public comment period

Fall 2007

\section{Record of Decision}

Post to the INL Administrative Record

Summer 2008

Release press release (and advertisement) to news media and other

Summer 2008 organizations

Conduct follow-up briefings with interested organizations and officials

Begin Summer 2008 


\section{REFERENCES}

42 USC $\S 9601$ et seq., 1980, "Comprehensive Environmental Response, Compensation and Liability Act of 1980," United States Code.

Holdren, K. Jean, Danny L. Anderson, Bruce H. Becker, Nancy L. Hampton, L. Don Koeppen, Swen O. Magnuson, and A. Jeff Sondrup, 2006, Remedial Investigation and Baseline Risk Assessment for Operable Unit 7-13/14, DOE/ID-11241, U.S. Department of Energy Idaho Operations Office.

DOE-ID, 2004, Community Relations Plan: A Guide to CERCLA Public Involvement in the Cleanup Program at the INEEL, DOE/NE-ID-11149, U.S. Department of Energy Idaho Operations Office. 